\title{
Exploring the Way Hotel Students Select Internship Employers
}

\author{
Chieh-Heng Ko \\ Department of Hospitality Management, College of Tourism and Hospitality, Da-Yeh University, Taiwan \\ Email: chko@mail.dyu.edu.tw
}

How to cite this paper: Ko, C.-H. (2021) Exploring the Way Hotel Students Select Internship Employers. Open Access Library Journal, 8: e8189.

https://doi.org/10.4236/oalib.1108189

Received: November 15, 2021

Accepted: December 18, 2021

Published: December 21, 2021

Copyright $\odot 2021$ by author(s) and Open Access Library Inc.

This work is licensed under the Creative Commons Attribution International License (CC BY 4.0).

http://creativecommons.org/licenses/by/4.0/

(c) (i) Open Access

\begin{abstract}
This study developed and tested a model to explore the way hotel students select internship employers based on their perceived importance of the criteria for selecting internship employers, which is grounded in the expectancy theory and job choice framework. Drawing from a self-administered survey of 273 hotel management college students in Taiwan, the study used cluster analysis to generate four clusters of students, namely learning enthusiasts, social support seekers, brand seekers, and school followers. Chi-square tests showed that school followers generally do not have internship experience. Implications for educators and internship employers are discussed in the paper.
\end{abstract}

\section{Subject Areas}

Human Resource Management, Tourism Economy

\section{Keywords}

Internship, Job Choice, Cluster Analysis

\section{Introduction}

The growth of the global hospitality and tourism industry has resulted in a huge volume of job opportunities [1]. However, the industry has encountered difficulties in attracting and retaining workers [2], leading to a mismatch between labor supply and demand. The labor shortage is not exclusive to a specific region of the world. A study conducted in Australia shows that over half of the participated hospitality and tourism students intended to find jobs in other industries [1]. An earlier study from Ireland demonstrates a high dropout rate from hospitality and tourism jobs [3]. These findings are not surprising, as tourism and hospitality jobs are generally demeaned in society, with people having negative 
attitudes toward the nature of the work [4]. Thus, even though new graduates may be willing to join the industry, they generally do not exhibit any inclination to stay in it for long [5], which in turn threatens its sustainability.

In this regard, incorporation of an internship program into curricula has been suggested as an effective solution to the problem [4] [6]. Internship is generally recognized as a bridge between classroom learning and industrial practice [5]. A positive internship experience encourages hospitality and tourism students to join the industry after graduation and promotes job satisfaction and willingness to stay in the industry [7]. Towards this end, there has been a recent upsurge in research aiming to provide recommendations for improving the effectiveness of internship programs in hospitality and tourism education [8]. Calls for related research are also growing. Cho [9] called for research on establishing a framework to guide effective implementation of internship programs. Similarly, Singh and Dutta [10] urged research in various countries to better identify the gap between internship expectations and experiences.

Most previous research has revolved around students' expectations and perceptions of internship programs [11], particularly in closing the gap between expectations and perceptions in order to derive students' satisfaction with their internship experience [2] [10]. Such work undeniably provides educators with useful insights when planning their internship programs. However, closing the gap provides the incomplete picture of students' internship satisfaction because importance of selection criteria also plays a crucial role in the formation of satisfaction [12]. Research on selection criteria is worthwhile as focusing educators' attention on the factors that students consider most important when selecting an internship employer will help to make their planning more effective.

Another major stream in the internship research provides a priori bounds for research on students' selection. Existing literature shows that perceptions of internship programs differ across students in terms of gender, previous experience, academic major, and so on [13] [14]. Following this rationale, research on students' selection criteria would be well conducted by segmenting the students based on their perceived importance of the selection criteria and then examining any possible difference among the groups. However, no relevant study thus far has been located in the existing literature.

Based on the above observations, this study conducted a survey among university students who were looking for an internship as part of a curriculum in a major tourism and hospitality management program in Taiwan. The objectives of this study are fourfold:

- To identify students' selection criteria when choosing internship employers;

- To examine and compare these criteria in terms of their corresponding importance from the students' perspective;

- To segment the students into groups based on their perceived importance of the criteria; and

- To examine the profile differences between the groups. 


\section{Literature}

Internship has attracted widespread attention from scholars in different disciplines [2] [10]. While different terms have been used in previous studies, such as experiential learning [15] [16], cooperative education [17], work-integrated learning [18], placement [10], and practicum [19], all these refer to "structured and career relevant work experiences obtained by students prior to graduation from an academic program" [20]. The goal is to enrich student learning by blending classroom learning with practical experience [5], so that students can have a realistic preview of their potential career [11], and can develop some workplaceoriented common sense before graduation [21]. Thus, many academic institutions make internship a compulsory subject for undergraduates, while some even extend it to the postgraduate curriculum [22]. Such kind of practice is not unexpected as internship programs provide considerable benefits for various stakeholders including students, employers, and academic institutions [10].

\subsection{Benefits and Threats of Internship}

From students' perspective, a major benefit from internship is to secure a job upon graduation [8]. Empirical studies also show that graduates with internship experience receive a job offer more quickly than those without [23]. Indeed, employers place more emphasis on the communication skills and critical thinking ability of job candidates, all of which can be fostered during internship, than on academic performance alone [16]. On the other hand, internship experiences enhance students' confidence [13]. Students with such experience behave more actively in lectures and seminars (for example, asking more questions) and display better academic performance than those without, albeit there is no difference in levels of motivation to study [13].

From the employers' perspective, they obtain academically-trained employees at a low cost to supplement their workforce. Internship also facilitates the employers to recruit adequate staff as they can make a more in-depth assessment of interns' performance than through a job interview [6]. Full-time employees who have previously worked as interns in the organization are likely to have more job satisfaction, because their expectations will be grounded in their experience and thus be more realistic [24].

Academic institutions also gain benefits. In terms of recruiting students, academic institutions offering such opportunities have an edge over others because prospective college students and their parents believe that internship facilitates job search upon graduation [6]. Moreover, such institutions can earn credibility if their interns perform well [25].

All these benefits tend to support the wider incorporation of internship into the curricula of most hospitality and tourism programs [6]. However, internship also has a dark side. Students who have an unpleasant experience are likely to form negative attitudes towards working in the industry and hence have less motivation to join it after graduation. As of the argument in previous studies [2] 
[26], it is very important to maintain students' satisfaction with their internship experience.

\subsection{Students' Satisfaction with Internship}

Regarding the formation of satisfaction, expectancy disconfirmation model [27] is an influential one. The model stipulates that satisfaction is in virtue of an evaluation of experience (i.e., perception) in relative to the anticipation (i.e., expectation) prior to the actual experience. If perception confirms expectation or is better than expectation (i.e., positive disconfirmation), satisfaction is resulted; whereas dissatisfaction is in virtue of a lower perception than expectation (i.e., negative disconfirmation). Given the significance of the model, previous research aiming at improving students' satisfaction with the internship experience has primarily focused on investigating their expectations and perceptions [28] [29].

Following the expectancy disconfirmation model, it is essential for educators and internship employers to better understand the factors that interns have high expectations, which in turn, are more likely to result in negative disconfirmation. Thus, relevant studies were not scant in the literature. A cross-national study conducted in Australia, the Netherlands, and the United Kingdom shows that interns generally expect the workplace to be characterized by high pressure, strong control from management, high commitment to the job by staff, a pleasant work environment, and little support from the supervisor [30]. Zopiatis [8] shows that students in Cyprus expect the internship experience to be related to their academic learning and to advance their personal and professional development. Lam \& Ching [2] indicated that interns have high expectations of enriching their work experience, developing technical skills, and creating future employability opportunities in the same company, but low expectations of extrinsic benefits like a competitive training allowance and fringe benefits. Based on these studies, it can be observed that the interns are generally concerned about career development, working environment, and the kind of training received. Although expectation is a key determinant of satisfaction, the influence of perception on satisfaction was argued to be even more profound [12].

In terms of perceptions, Cook et al. [25] found that after the internship, students highly appreciate the experience, feel they improved their ability to work with others, and enhance their confidence. Lee [16] added that interns perceive themselves as having gained a better understanding of how an organization functions, a stronger ability to form realistic career expectations, a wider network of professional contacts, an enhanced ability to take the initiative, an increased ability to adapt to change, and an improvement in their leadership and financial management skills. Based on the existing literature, it is observed that there is a plethora of studies on expectation and perception of internship. However, looking at expectations and perceptions separately cannot capture the full picture of satisfaction. Thus, other studies have attempted to compare perceptions and expectations among interns. 
A cross-national study conducted by Singh and Dutta [10] in the United Kingdom and India notes that interns' perceptions were generally lower than their expectations. Lam and Ching [2] also found that interns' perception lagged behind their expectations. The gaps were particularly salient in the domains of coordination between academic institutions and employers, bridging theories and workplace realities, and having a reasonable boss, all of which in turn led to low overall satisfaction. Obviously, to maintain the success of an internship program and achieve satisfaction, closing the gap between expectations and perceptions is a goal for educators all over the world [31]. The ideal situation is to ensure that every aspect of interns' expectations can be met. However, such an approach may not be effective, in particular that perception poses a greater impact on satisfaction than expectation. According to Patterson [12], the impact of perception on satisfaction is salient when the factor being evaluated is important. Thus, it should be more pragmatic for educators and internship employers to focus their improvement effort on the factors which students consider important [32]. Consistent with this argument, social psychological theories suggest that factors which are considered unimportant have little impact on subsequent evaluation [33]. Following this rationale, if strategies for improving interns' satisfaction address the factors which they feel are of little concern, such work will just be a waste of educators' time and effort. In this sense, it is imperative to investigate the factors that are most important to students, in particular at the stage of choosing internship employers, in order to concentrate efforts on these factors from the beginning and thus create a more accurate match between interns and employers. However, this issue seems to be neglected in the hospitality and tourism literature, though certain implications can be drawn from the limited studies regarding students' career choice upon graduation [1] [34]. To fill in this research gap, the factors that are important in driving the choice of internship employers by students have to be identified. Theory and framework are essential to form the foundation.

\subsection{Factors Driving Choice of Employer}

Vroom's [35] expectancy theory was widely adopted and considered the most influential one in studies about work-related criteria [36]. A major contention of the theory is that a person's desired outcome (e.g., satisfaction with the potential employer) is a function of a combination of outcomes (i.e., factors leading toward satisfaction) weighted by their valence, which represents the importance of the outcomes (i.e., the factors) [37]. This contention sets the ground for this study that a student's choice of internship employers, as a manifestation of satisfaction with the potential employer, is a function of the perceived importance of applicants' selection criteria of employers [38]. However, the expectancy theory does not specify the criteria that people harness upon their selection of employers. In this vein, this study follows the job choice framework developed by Behling, Labovitz, and Gainer [39]. The framework has widely been used to guide studies about choice of employers in the past [40] [41], albeit those studies were 
not in the internship context. The job choice framework posits three job choice factors, including an objective factor, a subjective factor, and a critical contact factor. The objective factor represents some common and fundamental needs of job applicants like salary, fringe benefits, promotion opportunities, and others [40]. Empirical studies show that the objective factor tended to be the major consideration of students at the job seeking stage [42]. Hospitality and tourism students are of no exception [1] [34].

The subjective factor suggests that job seekers look for an employer who will satisfy their psychological needs, specifically in the realm of emotional benefits [39]. Among various subjective factors, the work environment is a major consideration for job seekers [35]. Echoing this argument, one study of accounting students reports that the personalities of the supervisor and co-workers are important in the choice of employers [43]. On the other hand, the subjective factor also accounts for job seekers' concerns about the image of the organization. Indeed, they may perceive that joining a reputable organization will help to enhance their personal pride [44]. They will also perform a mapping exercise between their personal characteristics and their perceptions of the organization [45]. Such a mapping implies that individual differences will affect job selection criteria, which resonates with previous findings that such criteria vary with culture [46], gender, age, and work experience [47].

The critical contact factor is based on the precondition that a job applicant has failed to differentiate the aforementioned objective and subjective factors offered by different potential employers, and base their decisions on their direct contact with organizations [39]. This argument can be applied to students, who perhaps have less knowledge about organizations than more experienced job seekers. In this regard, they may make a choice of internship employer based on their experience with the organization, for instance, whether it is affiliated with their academic institution or they have had a consumption experience with it.

\section{Methodology}

A structured questionnaire was designed to collect quantitative data. It contained 10 items measuring the perceived importance of the selection criteria of internship employers. Grounded in the job choice framework [39], these items were adapted from previous studies [48], including "relevance of internship to career development," "functional area of the internship," "physical working environment," "comprehensive training program," "friendly colleagues," "brand of the organization," "competitive remuneration," "distance commuting to workplace," "experience of the company as a consumer," and "working in an organization that is affiliated with the university". A 7-point Likert-type scale (ranging from $1=$ very unimportant to 7 = very important) was used to capture responses of these items. Finally, demographic information on the participants including gender, local/nonlocal studentship, academic majors (hotel or tourism management), and internship experience was collected. These demographic factors were commonly used in previous studies [43] and were of practical significance from 
the perspectives of internship officers who were involved in this study.

A major hotel and tourism management program in Taiwan, which has its own training hotel and restaurant, was selected as the research setting for this study. The target respondents were students who were seeking an internship as part of a curriculum in the school. To derive the final version of the questionnaire for this study, the investigators invited several contents experts including established researchers in tourism and hospitality and executive officers in internship programs to ensure the content validity of measurement items. In addition, four graduate students in this school were invited to provide comments on the initial instrument. Several minor suggestions for rewording were received. The revised questionnaire was then dispatched to 173 college students via email in December 2020 and a total of 21 students participated in the pilot test. No further suggestions were received. Then, for the main survey, an invitation email followed by a reminder, for increasing the response rate, was sent to all 1109 students in the same school in year 2021. A filtering question was used to screen out those students who had filled in the questionnaire before. Finally, $280 \mathrm{com}-$ pleted questionnaires were received, resulting in a response rate of $25.2 \%$. Of which, 274 were determined usable after excluding six questionnaires with missing values. All the participants partook in the survey on a voluntary basis and no incentive was provided.

The response rate in this study indicated that a majority of the target population did not participate in our survey. Hence, non-response bias of the samples was assessed by comparing all measurement items between the first and the last 50 respondents with independent samples $t$-test. Since no significant difference was found (see Table 1), non-response bias was not a concern for this study.

Cluster analysis was used to segment the participants based on their evaluation of the importance of the 10 variables in this study. Given that multicollinearity among variables would undermine the results of such a cluster analysis, a correlation matrix was generated amongst the 10 variables with a factor analysis using the principal component method with varimax rotation. Two variables including "relevance of internship to career development" and "functional area of the internship" were strongly correlated to several other variables (correlation coefficient $>0.9)$ whilst the determinant value of the matrix (2.13E-006) was less than 0.00001 , indicating the existence of multicollinearity. Hence, these two variables were removed from the subsequent analyses. A correlation matrix was generated again with the remaining eight variables. However, the determinant value $(0.000)$ was still less than 0.00001 , albeit all correlation coefficients were below 0.9. Of the coefficients, the strongest was between "physical working environment" and "friendly colleagues" (0.894). The variable "friendly colleagues" was retained for subsequent analysis as it had been frequently mentioned by interns in a previous study conducted in Hong Kong [48]. The determinant value of the seven remaining variables based on the factor analysis (0.001) was greater than 0.00001 , indicating that the multicollinearity problem had been resolved. 
Table 1. Statistics of non-response bias.

\begin{tabular}{ccccc}
\hline Variables & $\begin{array}{c}\text { First 50 } \\
\text { samples }\end{array}$ & $\begin{array}{c}\text { Last 50 } \\
\text { samples }\end{array}$ & t-Value & df \\
\hline Friendly colleagues & M (SD) & M (SD) & & \\
\hline Comprehensive training program & $3.94(2.289)$ & $4.14(2.548)$ & -0.413 & 98 \\
Competitive remuneration & $3.92(1.771)$ & $4.00(1.917)$ & -0.217 & 98 \\
Brand of the organization & $3.96(2.240)$ & $3.88(1.986)$ & 0.189 & 98 \\
Experience of the company as a consumer & $4.04(1.414)$ & $4.12(1.757)$ & $-0.251^{\#}$ & $93.704^{\#}$ \\
Distance commuting to the workplace & $4.20(1.641)$ & $4.06(1.845)$ & 0.401 & 98 \\
Working in an organization that is affiliated & $3.98(1.301)$ & $4.24(1.546)$ & -0.910 & 98 \\
with the university & $3.80(1.959)$ & $4.12(2.210)$ & $-0.766^{\#}$ & $96.608^{\#}$ \\
Physical working environment & $3.82(2.345)$ & $4.26(2.406)$ & -0.926 & 98 \\
Functional area of the internship & & & & \\
$\begin{array}{c}\text { Relevance of internship to career } \\
\text { development }\end{array}$ & $3.88(2.362)$ & $4.00(2.373)$ & -0.253 & 98 \\
\hline
\end{tabular}

"Represents the statistics was based on the fact that Levene's tests were not passed ( $p<$ $0.05)$.

While outliers can reduce the representativeness of the results of a cluster analysis, the average dissimilarity of each observation was calculated. The largest dissimilarity was 8.53 , whereas the second and third largest (8.24 and 8.20) were proximate to each other; hence, the observation with the largest dissimilarity was considered as an outlier and eliminated. In consequence, 273 observations were retained. Then, a further correlation matrix was produced using factor analysis. Multicollinearity was not identified here, given that the determinant value was $0.002(4.00001)$ and the correlations were not very strong $($ i.e. $<0.9)$.

Hierarchical cluster analysis with the Ward method and Squared Euclidean distance was then employed to determine the appropriate number of clusters. The data were standardized with $z$-scores in order to control the adverse effects on the cluster solution caused by large standard deviations (ranging from 1.393 to 2.373 in this study). Then, a k-Means cluster analysis was performed to segment the participants. Also, $\chi^{2}$ tests were conducted to examine whether the segments varied with gender, being local (or nonlocal), academic major (hotel or tourism management), and internship experiences (with or without).

\section{Results}

Among the 273 respondents, 218 (79.9\%) were females, denoting the typical gender distribution of hospitality and tourism management programs. Most respondents were local students $(\mathrm{n}=234 ; 85.7 \%)$, majoring in hotel management $(\mathrm{n}=$ $180 ; 65.9 \%)$, and had some prior internship experience $(n=195 ; 71.4 \%)$. Table 2 shows the demographic profile of the respondents. 
Table 2. Demographic profile of the respondents.

\begin{tabular}{ccccccc}
\hline & Freq. Percent & Freq. Percent \\
\hline Gender & & \multicolumn{5}{c}{ Academic major } \\
Male & 55 & 20.1 & Hotel management & 180 & 65.9 \\
Female & 218 & 79.9 & Tourism management & 93 & 34.1 \\
Local and nonlocal student & & & Previous internship experience & \\
Local & 234 & 85.7 & Yes & 195 & 71.4 \\
Nonlocal & 39 & 14.3 & No & 78 & 28.6 \\
\hline
\end{tabular}

Among the seven selection criteria, six had a mean value greater than 4 , including "friendly colleagues" ( $\mathrm{M}=4.38, \mathrm{SD}=2.373)$, followed by "brand of the organization" ( $\mathrm{M}=4.33, \mathrm{SD}=2.065)$, "comprehensive training program" ( $\mathrm{M}=$ $4.32, \mathrm{SD}=2.318)$, “competitive remuneration" $(\mathrm{M}=4.31, \mathrm{SD}=1.795)$, "distance commuting to the workplace" ( $\mathrm{M}=4.25, \mathrm{SD}=1.736)$, and "experience of the company as consumer" $(\mathrm{M}=4.12, \mathrm{SD}=1.535)$. Only "working in an organization that is affiliated with the university" ( $M=3.93, S D=1.393)$ had a mean value below 4 . Table 3 presents the criteria in terms of their mean values. Although the mean values of the criteria appeared different from each other, the results of paired sample $t$-tests revealed that there was no statistically significant difference between the mean scores of the top five criteria $(p>0.05)$. Significant differences were only found in the pair comparisons between the two bottom criteria and some other criteria. More specifically, "experience of the company as a consumer" was less important than "friendly colleagues" (mean difference = $-0.26, p<0.05$ ), "brand of the organization" (mean difference $=-0.21, p<0.05$ ), and "competitive remuneration" (mean difference $=-0.19, p<0.05$ ). "Working in an organization that is affiliated with the university" was less important than "friendly colleagues" (mean difference $=-0.45, p<0.01$ ), "brand of the organization" (mean difference $=0.40, p<0.01$ ), "competitive remuneration" (mean difference $=-0.39, p<0.05$ ), "competitive remuneration" (mean difference $=.38, p<0.01$ ), and "distance commuting to the workplace" (mean difference $=$ $0.32, p<0.01)$.

In order to obtain a manageable number of clusters, the solution was selected between two and seven clusters inclusively. The results of the hierarchical cluster analysis indicated that a three-cluster solution was the most adequate since the largest percentage increase of heterogeneity was from three to two clusters, except for the percentage increase from two to one cluster which is usually the highest and therefore commonly ignored. The results of the $k$-Means cluster analysis identified three groups of participants (see Table 4) and ANOVA tests indicated significant differences between them on each of the seven variables ( $p$ $<0.001$ ). However, as Table 4 illustrates, participants belonging to cluster three tended to indicate that all variables were important to them, whereas those in cluster two tended to indicate that all variables were unimportant and cluster 
one appeared to be somewhere in between. These results suggest the existence of response-style effects where respondents tend to maintain a consistent response pattern. Hence, within-case standardization was performed to eliminate these effects.

Table 3. Statistics of selection criteria of internship employer.

\begin{tabular}{|c|c|c|c|c|c|c|c|c|}
\hline $\begin{array}{l}\text { Selection criteria of } \\
\text { internship employer }\end{array}$ & $\begin{array}{l}\text { Mean } \\
(\mathrm{M})\end{array}$ & $\begin{array}{l}\text { Standard } \\
\text { deviation } \\
(\mathrm{SD})\end{array}$ & $\begin{array}{l}\text { Column } \\
\text { items }\end{array}$ & & & & & \\
\hline & & & $\begin{array}{l}\text { Friendly } \\
\text { colleagues }\end{array}$ & $\begin{array}{l}\text { Brand of the } \\
\text { organization }\end{array}$ & $\begin{array}{l}\text { Comprehensive } \\
\text { training } \\
\text { program }\end{array}$ & $\begin{array}{l}\text { Competitive } \\
\text { remuneration }\end{array}$ & $\begin{array}{l}\text { Distance } \\
\text { commuting to } \\
\text { the workplace }\end{array}$ & $\begin{array}{l}\text { Experience of } \\
\text { the company as } \\
\text { a consumer }\end{array}$ \\
\hline Row items & & & \multicolumn{6}{|c|}{ Row items minus column items ( $t$-value), $d f=272$} \\
\hline Friendly colleagues & 4.38 & 2.373 & & & & & & \\
\hline $\begin{array}{l}\text { Brand of the } \\
\text { organization }\end{array}$ & 4.33 & 2.065 & $\begin{array}{l}-0.05 \\
(-0.665)\end{array}$ & & & & & \\
\hline $\begin{array}{l}\text { Comprehensive training } \\
\text { program }\end{array}$ & 4.32 & 2.318 & $\begin{array}{l}-0.06 \\
(-0.912)\end{array}$ & $\begin{array}{l}-0.01 \\
(-0.218)\end{array}$ & & & & \\
\hline $\begin{array}{l}\text { Competitive } \\
\text { remuneration }\end{array}$ & 4.31 & 1.795 & $\begin{array}{l}-0.07 \\
(-0.861)\end{array}$ & $\begin{array}{l}-0.02 \\
(-0.307)\end{array}$ & $\begin{array}{l}-0.01 \\
(-0.099)\end{array}$ & & & \\
\hline $\begin{array}{l}\text { Distance commuting } \\
\text { to the workplace }\end{array}$ & 4.25 & 1.736 & $\begin{array}{l}-0.13 \\
(-1.35)\end{array}$ & $\begin{array}{l}-0.08 \\
(-0.861)\end{array}$ & $\begin{array}{l}-0.07 \\
(-0.638)\end{array}$ & $\begin{array}{l}-0.06 \\
(-0.736)\end{array}$ & & \\
\hline $\begin{array}{l}\text { Experience of the } \\
\text { company as a consumer }\end{array}$ & 4.12 & 1.535 & $\begin{array}{l}-.26^{*} \\
(-2.339)\end{array}$ & $\begin{array}{l}-0.21^{*} \\
(-2.038)\end{array}$ & $\begin{array}{l}-0.20 \\
(-1.701)\end{array}$ & $\begin{array}{l}-0.19^{*} \\
(-2.086)\end{array}$ & $\begin{array}{l}-0.13 \\
(-1.599)\end{array}$ & \\
\hline $\begin{array}{l}\text { Working in an } \\
\text { organization that is } \\
\text { affiliated with the } \\
\text { university }\end{array}$ & 3.93 & 1.393 & $\begin{array}{l}-0.45^{* *} \\
(-2.791)\end{array}$ & $\begin{array}{l}-0.40^{* *} \\
(-2.664)\end{array}$ & $\begin{array}{l}-0.39^{*} \\
(-2.427)\end{array}$ & $\begin{array}{l}-0.38^{* *} \\
(-2.948)\end{array}$ & $\begin{array}{l}-0.32^{* *} \\
(-2.756)\end{array}$ & $\begin{array}{l}-0.19 \\
(-1.795)\end{array}$ \\
\hline
\end{tabular}

${ }^{\star}$ Represents $p<0.05 ;{ }^{\star *}$ Represents $p<0.01$.

Table 4. Statistics of selection criteria of internship employer across clusters.

\begin{tabular}{|c|c|c|c|c|c|}
\hline & $\begin{array}{l}\text { Cluster } 1(\mathrm{n}=81) \\
\qquad \mathrm{M}(\mathrm{SD})\end{array}$ & $\begin{array}{l}\text { Cluster } 2(\mathrm{n}=117) \\
\qquad \mathrm{M}(\mathrm{SD})\end{array}$ & $\begin{array}{l}\text { Cluster } 3(\mathrm{n}=75) \\
\qquad \mathrm{M}(\mathrm{SD})\end{array}$ & $F$-value & $d f$ \\
\hline Friendly colleagues & $6.14(0.833)$ & $1.84(0.880)$ & $6.44(0.919))$ & $859.892^{*}$ & 2 \\
\hline Comprehensive training program & $6.05(0.921)$ & $1.82(0.805)$ & $6.33(0.741)$ & $938.613^{*}$ & 2 \\
\hline Competitive remuneration & $5.44(0.987)$ & $2.53(0.952)$ & $5.85(0.780)$ & $396.523^{*}$ & 2 \\
\hline Brand of the organization & $6.01(0.915)$ & $2.16(0.840)$ & $5.89(0.815)$ & $655.939^{*}$ & 2 \\
\hline Experience of the company as a consumer & $4.35(1.266)$ & $3.03(1.133)$ & $5.59(0.887)$ & $122.986^{*}$ & 2 \\
\hline Distance commuting to the workplace & $4.86(1.046)$ & $2.72(1.159)$ & $5.99(0.780)$ & $248.922^{*}$ & 2 \\
\hline $\begin{array}{l}\text { Working in an organization that is affiliated with the } \\
\text { university }\end{array}$ & $2.96(1.042)$ & $3.88(1.353)$ & $5.05(0.884)$ & $64.542^{*}$ & 2 \\
\hline
\end{tabular}

${ }^{\star}$ Represents $p<0.001$. 
The results of the hierarchical cluster analysis with the within-case standardized data revealed that, except for the two-cluster solution, the percentage increase of heterogeneity of a three-cluster solution was the highest (10.12\%), followed by a four- (8.53\%) and a five-cluster solution (7.27\%). Based on the $\mathrm{k}-$ Means results, the ANOVA tests of all these solutions indicated that all the selection criteria were significantly different between the clusters. While threecluster solution had the largest heterogeneity increase, the solution seems to be most adequate in this study. Despite this, stability of the solution has to be assessed in order to minimize the risk of accepting a cluster solution specific to the sample (Hair et al., 2010).

To assess the stability of the cluster solutions, Hair et al.'s (2010) suggestions were followed. The observations were sorted in order ranging from "with internship experience" to "without internship experience." Then, the k-Means cluster analyses were performed again for three, four, and five clusters separately (second $k$-Means) and the results were compared with those of the first k-Means (that is, performed before sorting the data). Table 5 summarizes the results of the comparisons, in which the four-cluster solution performed the best in terms of stability since the clusters generated from the second k-Means contained the largest proportion of observations clustered in the first $k$-Means (78\%). This percentage indicates that the solution is fairly stable. Therefore, this study adopted the four-cluster solution, even though its percentage increase of heterogeneity was not as high as the three-cluster solution.

As indicated in Table 6, the first cluster $(n=38$; proportion $=14 \%$ ), which was also the smallest group, had the highest mean score for "comprehensive training program" $(\mathrm{M}=0.9687$; $\mathrm{SD}=0.5928)$, followed by "friendly colleagues" $(\mathrm{M}=0.5947 ; \mathrm{SD}=0.6969)$. The least-important criterion for this group was "brand of the organization" $(M=0.6540 ; S D=0.5978)$ whilst the second-least important was "working in an organization that is affiliated with the university" $(\mathrm{M}=0.5565 ; \mathrm{SD}=0.7635)$. Based on the fact that a comprehensive training program was paramount for the first cluster, the authors classified this group as learning enthusiasts. The second cluster $(n=66$; proportion $=24 \%)$ emphasized "friendly colleagues" $(\mathrm{M}=0.7772 ; \mathrm{SD}=0.5232)$, followed by "brand of the organization" $(\mathrm{M}=0.4755 ; \mathrm{SD}=0.5048)$. This group rated "working in an organization that is affiliated with the university" as the least important $(\mathrm{M}=1.7836$; $\mathrm{SD}=0.2779)$ and "experience of the company as a consumer" $(\mathrm{M}=0.0749 ; \mathrm{SD}=$ 0.4547 ) as the second-least important. This group was labeled as social support seekers. The third cluster $(n=58$; proportion $=21 \%$ ) was described as brand seekers, given that "brand of the organization" was its major concern $(\mathrm{M}=$ 0.8882 ; $\mathrm{SD}=0.5460)$. The second-most important criterion for this group was "friendly colleagues" $(\mathrm{M}=0.6062 ; \mathrm{SD}=0.6735)$, whereas the least important was "experience of the company as a consumer" $(\mathrm{M}=1.0796 ; \mathrm{SD}=0.5152)$ and the second-least important was "working in an organization that is affiliated with the university" $(\mathrm{M}=0.7905 ; \mathrm{SD}=0.6130)$. Regarding the fourth cluster, which 
was also the largest group $(n=111$; proportion $=41 \%)$, students tended to put most weight on "working in an organization that is affiliated with the university" $(\mathrm{M}=1.2176 ; \mathrm{SD}=0.6790)$ followed by "experience of the company as a consumer" $(M=0.4749 ; \mathrm{SD}=0.6888)$. The authors labeled these students as school followers who perceived "friendly colleagues" as the least-important criterion (M $=0.7754 ; \mathrm{SD}=0.5807)$ and "comprehensive training program" $(\mathrm{M}=0.6792 ; \mathrm{SD}$ $=0.5761)$ as the second-least important.

In order to investigate the profile differences between groups, they were crosstabulated with gender, local/nonlocal, academic major, and internship experience (see Table 7). The results of the $\chi^{2}$ tests showed that gender, locality, and major did not vary across groups $(p>0.05)$. Internship experience was the only statistically significant variable that explained the variations among the groups $\left(\chi^{2}=22.248, p<0.001\right)$. More specifically, students without internship experience were more likely to be school followers (62.8\%), but less likely to be learning enthusiasts (9\%), social support seekers $(15.4 \%)$, or brand seekers (12.8\%) than students with internship experience (31.8\% for school followers, $15.9 \%$ for learning enthusiasts, $27.7 \%$ for social support seekers, and $24.6 \%$ for brand seekers).

Table 5. Stability of the cluster solutions.

\begin{tabular}{ccc}
\hline Cluster solutions & Observations in the 1st $k$-Means clustering again in the 2nd $k$-Means \\
\hline & Freq. & Percent $^{\mathrm{a}}$ \\
4 & 193 & 70.7 \\
5 & 213 & 78.0 \\
\hline
\end{tabular}

${ }^{\mathrm{a}}$ Freq/273.

Table 6. Statistics of selection criteria of internship employer across clusters (standardized data).

\begin{tabular}{|c|c|c|c|c|c|c|}
\hline & $\begin{array}{l}\text { Cluster } 1(\mathrm{n}=38) \\
\mathrm{M}(\mathrm{SD})\end{array}$ & $\begin{array}{l}\text { Cluster } 2(\mathrm{n}=66) \\
\mathrm{M}(\mathrm{SD})\end{array}$ & $\begin{array}{l}\text { Cluster } 3(\mathrm{n}=58) \\
\mathrm{M}(\mathrm{SD})\end{array}$ & $\begin{array}{l}\text { Cluster } 4(\mathrm{n}=111) \\
\text { M (SD) }\end{array}$ & $F$-value & $d f$ \\
\hline Friendly colleagues & $0.5947(0.6969)$ & $0.7772(0.5232)$ & $0.6062(0.6735)$ & $-0.7754(0.5807)$ & $126.648^{* * *}$ & 3 \\
\hline Comprehensive training program & $0.9687(0.5968)$ & $0.3282(0.6713)$ & $0.5345(0.6677)$ & $-0.6792(0.5761)$ & $95.666^{* * *}$ & 3 \\
\hline Competitive remuneration & $-0.2582(0.7769)$ & $0.2257(0.4802)$ & $0.0655(0.7062)$ & $0.0204(0.6227)$ & $4.744^{* *}$ & 3 \\
\hline Brand of the organization & $-0.6540(0.5978)$ & $0.4755(0.5048)$ & $0.8882(0.5460)$ & $-0.3933(0.6598)$ & $88.411^{* * *}$ & 3 \\
\hline $\begin{array}{l}\text { Experience of the company as a } \\
\text { consumer }\end{array}$ & $0.0639(0.7417)$ & $-0.0749(0.4547)$ & $1.0796(0.5152)$ & $0.4749(0.6888)$ & $82.117^{* * *}$ & 3 \\
\hline Distance commuting to the workplace & $-0.1587(0.8710)$ & $0.0518(0.5966)$ & $-0.2242(0.6505)$ & $0.1349(0.8101)$ & $3.689^{*}$ & 3 \\
\hline $\begin{array}{l}\text { Working in an organization that is } \\
\text { affiliated with the university }\end{array}$ & $-0.5565(0.7635)$ & $-1.7836(0.2779)$ & $-0.7905(0.6130)$ & $1.2176(0.6790)$ & $375.624^{* * *}$ & 3 \\
\hline Cluster name & $\begin{array}{l}\text { Learning } \\
\text { enthusiasts }\end{array}$ & $\begin{array}{l}\text { Social support } \\
\text { seekers }\end{array}$ & -Brand seekers & School followers & & \\
\hline
\end{tabular}

Note: All values were produced from within-case standardized data; ${ }^{\star * *}$ Represents $p<0.001 ;{ }^{*}$ Represents $p<0.01 ;{ }^{\star}$ Represents $p$ $<0.05$. 
Table 7. Results of $\chi^{2}$ tests.

\begin{tabular}{|c|c|c|c|c|c|c|}
\hline & Learning enthusiasts & Social support seekers & Brand seekers & School followers & $x^{2}$ & $\mathrm{df}$ \\
\hline \multicolumn{7}{|l|}{ Gender - n (\%) } \\
\hline Male & $9(16.4 \%)$ & $14(25.5 \%)$ & $11(20.0 \%)$ & $21(38.2 \%)$ & \multirow[t]{2}{*}{0.496} & \multirow[t]{2}{*}{3} \\
\hline Female & $29(13.3 \%)$ & $52(23.9 \%)$ & $47(21.6 \%)$ & $90(41.3 \%)$ & & \\
\hline \multicolumn{7}{|l|}{ Local student - n (\%) } \\
\hline Yes & $31(13.2 \%)$ & $59(25.2 \%)$ & $49(20.9 \%)$ & $95(40.6 \%)$ & \multirow[t]{2}{*}{1.334} & \multirow[t]{2}{*}{3} \\
\hline No & $7(17.9 \%)$ & $7(17.9 \%)$ & $9(23.1 \%)$ & $16(41.0 \%)$ & & \\
\hline \multicolumn{7}{|l|}{ Academic major - n (\%) } \\
\hline Hotel management & $24(13.3 \%)$ & $42(23.3 \%)$ & $40(22.2 \%)$ & $74(41.1 \%)$ & \multirow[t]{2}{*}{0.549} & 3 \\
\hline Tourism management & $14(15.1 \%)$ & $24(25.8 \%)$ & $18(19.4 \%)$ & $37(39.8 \%)$ & & \\
\hline \multicolumn{7}{|c|}{ With internship experience $-\mathrm{n}(\%)$} \\
\hline Yes & $31(15.1 \%)$ & $54(27.7 \%)$ & $48(24.6 \%)$ & $62(31.8 \%)$ & \multirow{2}{*}{\multicolumn{2}{|c|}{$22.248^{*}$}} \\
\hline No & $7(9.0 \%)$ & $12(15.4 \%)$ & $10(12.8 \%)$ & $49(62.8 \%)$ & & \\
\hline
\end{tabular}

${ }^{\star}$ Represents $p<0.001$.

\section{Discussion}

According to the expectancy theory, students' choice of internship employers is a function of the selection criteria of employers weighted by the perceived importance. This study aimed to identify and compare the importance of selection criteria used by students in choosing internship employers. Grounded in the job choice framework, ten criteria were identified and subject to a rigorous assessment of content validity. Seven of them were retained for analysis in this study given the multicollinearity issue. Our results showed that the subjective factors of job choice framework (such as friendly colleagues and brand of the organization) are equally important to the objective factors (such as a comprehensive training program, competitive remuneration, and commute distance) while those critical factors (such as experience of the company as a consumer and working in an organization that is affiliated with the university) are relatively less important. The findings refute previous studies that objective factors were perceived more important than subjective factors upon seeking job/internship opportunities [1] [34] [42].

While ranking of the importance of these criteria provides an overview of the factors to which educators should pay more attention, the findings do not help them to cater for the needs of individual students. Segmenting the students based on their perceived importance of the criteria (i.e., the third objective of this study) is necessary in this regard. The segmentation approach enriches the literature as existing studies primarily focused on identifying and classifying factors about internship experience [2] [10] [48], rather than classifying students based on perceived importance of the selection criteria of internship employers. The results of the cluster analyses showed that four groups of students can be identi- 
fied based on their evaluation of the importance of selection criteria, including learning enthusiasts, social support seekers, brand seekers, and school followers. Learning enthusiasts were most concerned about the training program and least worried about branding. This group placed most weight on an objective factor (that is, comprehensive training program) and least on a subjective factor (that is, brand of the organization). This finding echoes with Behling et al.'s [39] argument that a critical contact factor plays a salient role only when job seekers encounter difficulties on prioritizing objective and subjective factors. In this case, the objective factor, particularly on comprehensive training program, outweighed subjective factor from learning enthusiasts' perspective so that critical contact factors like consumption experience with the organization and working in an organization affiliated with the university were not perceived as important.

Social support seekers and brand seekers tended to concern about subjective factors like friendly colleagues and branding. However, given that the top-rated criterion of both groups was different, different labels were used. Social support seekers emphasized their need for friendly colleagues. In contrast, brand seekers stressed the brand of the organization. On the other hand, these two groups' lowest-ranked criteria were also different (that is, working in an organization that is affiliated with the university for social support seekers, and experience of the company as a consumer for brand seekers). However, it can be observed that both criteria are related to the critical contact factor. In summary, the importance of subjective factor is so high that the role of critical contact becomes minimal. This finding further confirms Behling et al.'s [39] argument that a critical contact factor is unimportant if people manage to distinguish their preferences between subjective and objective factors.

The school followers were the typical endorsers of critical contact factor as they tended to select an organization affiliated with the university and based their decisions on their consumption experience with it. Moreover, they did not show any preference for subjective over objective factors or vice versa. Therefore, our findings are again consistent with Behling et al.'s [39] contention that school followers used critical contacts to make a decision as they encountered a dilemma between subjective and objective factors.

Based on the group size, it can be observed that most students were school followers $(41 \%)$. The size of social support seekers $(24 \%)$ and brand seekers (21\%) were close to each other. The smallest group was learning enthusiasts (14\%). The group size indicates that subjective factor was of students' major concern when they looked for internship employers because social support seekers and brand seekers jointly occupied the largest proportion (45\%). Interestingly, contrary to previous findings that objective factor tended to top job applicants' mind [1] [34] [42], the groups that mainly favored subjective factor dominated the samples in our study whereas the group that most favored the objective factor was smallest.

To achieve the fourth objective regarding profiling of the segments, the cur- 
rent study made an attempt to distinguish the four groups based on four profile variables including gender, local/nonlocal, academic majors (hotel or tourism management), and internship experience. The first three variables made no significant difference across groups. This is somewhat surprising as these variables have been reported to moderate job choice [43] [46]. While internship experience was the only variable that differentiated the groups, students without this tended to be school followers. This is not surprising because students without any internship experience are likely to have little knowledge about the industry and limited connections within it. Relatively speaking, they will be more familiar with organizations affiliated with their university and hence more likely to choose them. In this regard, the training hotels and restaurants at the university play a vital role in resolving the uncertainty of internship freshmen.

\section{Implications and Conclusions}

This study has shown that subjective factors like friendly colleagues and organizational brand, and objective factors like competitive remuneration, brand of the organization, experience of the company as a consumer, and distance commuting to the workplace are more important than critical contact factors like experience of the company as a consumer and working in an organization that is affiliated with the university when students select their internship employers. However, our segmentation approach has shown that these findings are not necessarily robust across individual students as some placed more emphasis on objective factors (learning enthusiasts), some stressed on subjective factors (social support seekers and brand seekers), whereas others tended to select organizations affiliated with their university (school followers).

While importance of the selection criteria of internship employers varies with students, students should not be perceived as homogeneous. Educators and industry practitioners should survey the students who are about to commence their internship so as to understand which segment (i.e., learning enthusiasts, social support seekers, brand seekers, and school followers) the students belong to. Also, to have a better understanding about the strength and weakness of an internship employer, educators may evaluate interns' satisfaction level with the internship employer based on the selection criteria. Then, a better student-employer fit can be achieved, which in turn may benefit students' satisfaction with the internship experience and thus intention to work in the industry and even with the same employer after graduation.

In line with Behling et al.'s [39] contention in their job choice framework, our findings show that students will rely on critical contact to select an internship employer (e.g., school followers) if they encounter difficulties in prioritizing objective and subjective factors. Accordingly, students who managed to prioritize the objective (e.g., learning enthusiasts) and subjective factors (e.g., social support seekers and brand seekers) tended to perceive critical contact as being unimportant. Contrary to most previous findings that objective factor is most sa- 
lient in job seeking, endorsers of subjective factors (i.e., social support seekers and brand seekers) are the majority in our study. It is important for employers to provide support for interns and educators to strive for more internship cooperation with renowned organizations.

As this study shows that school followers also prevail among students and they tend to lack internship experience, it is recommended that educators allocate most (if not all) of their organizations' (e.g., the training hotel and restaurant) internship quotas to the school followers, especially those without previous experience. For the schools which do not have any training organization, they are recommended to establish one.

While most existing studies, including the current one, are interested in students' perspective on internship, future research may extend the literature of internship by investigating employers' perspectives on the outcomes associated with internship like the additional workload involved.

Given that this study used a conventional segmentation vehicle (cluster analysis), future studies may deploy other methods like $\chi^{2}$ automatic interaction detection (CHAID) and latent class analysis.

In addition to those identified in the current study, other selection criteria might be salient as well. However, quantitative approach may not be ideal to capture all the criteria owing to the limited length of survey. In this regard, future research may consider qualitative approach like in-depth interview.

Despite its contribution to the literature, the current study is not without limitations. First, this study was conducted in one hotel and tourism school in Taiwan, and so generalizability of the findings cannot be made. Although stability of our cluster solutions has been confirmed, our findings may not be representative of other academic institutions and countries. Future studies may attempt to replicate the segmentation approach in other settings so that replicability and validity of the findings in this study can be assessed. Furthermore, as only four profile variables including gender, local/nonlocal, academic major, and internship experience were deployed to differentiate between clusters, future studies may add more variables (such as grade point average and personality factors) in order to generate more implications for educators.

\section{Conflicts of Interest}

The author declares no conflicts of interest.

\section{References}

[1] Richardson, S. (2008) Undergraduate Tourism and Hospitality Students Attitudes toward a Career in the Industry: A Preliminary Investigation. Journal of Teaching in Travel \& Tourism, 8, 23-46. https://doi.org/10.1080/15313220802410112

[2] Lam, T. and Ching, L. (2007) An Exploratory Study of an Internship Program: The Case of Hong Kong Students. International Journal of Hospitality Management, 26, 336-351. https://doi.org/10.1016/j.ijhm.2006.01.001

[3] O’Leary, S. and Deegan, J. (2005) Career Progression of Irish Tourism and Hospi- 
tality Management Graduates. International Journal of Contemporary Hospitality Management, 17, 421-432. https://doi.org/10.1108/09596110510604841

[4] Kusluvan, S. and Kusluvan, Z. (2000) Perceptions and Attitudes of Undergraduate Tourism Students towards Working in the Tourism Industry in Turkey. Tourism Management, 21, 251-269. https://doi.org/10.1016/S0261-5177(99)00057-6

[5] Jiang, B. and Tribe, J. (2010) 'Tourism Jobs-Short Lived Professions': Student Attitudes towards Tourism Careers in China. Journal of Hospitality, Leisure, Sport \& Tourism Education, 9, 4-19.

[6] Yiu, M. and Law, R. (2012) A Review of Hospitality Internship: Different Perspectives of Students, Employers, and Educators. Journal of Teaching in Travel \& Tourism, 12, 377-402. https://doi.org/10.1080/15313220.2012.729459

[7] Chathoth, P.K., Mak, B., Sim, J., Jauhari, V. and Manaktola, K. (2011) Assessing Dimensions of Organizational Trust across Cultures: A Comparative Analysis of U.S. and Indian Full Service Hotels. International Journal of Hospitality Management, 30, 233-242. https://doi.org/10.1016/j.ijhm.2010.09.004

[8] Zopiatis, A. (2007) Hospitality Internships in Cyprus: A Genuine Academic Experience or a Continuing Frustration? International Journal of Contemporary Hospitality Management, 19, 65-77. https://doi.org/10.1108/09596110710724170

[9] Cho, M. (2006) Student Perspectives on the Quality of Hotel Management Internships. Journal of Teaching in Travel \& Tourism, 6, 61-76. https://doi.org/10.1300/J172v06n01_04

[10] Singh, A. and Dutta, K. (2010) Hospitality Internship Placements: Analysis for United Kingdom and India. Journal of Services Research, 10, 85-99.

[11] Siu, G., Cheung, C. and Law, R. (2012) Developing a Conceptual Framework for Measuring Future Career Intention of Hotel Interns. Journal of Teaching in Travel \& Tourism, 12, 188-215. https://doi.org/10.1080/15313220.2012.678220

[12] Patterson, P.G. (1993) Expectations and Product Performance as Determinants of Satisfaction for a High-Involvement Purchase. Psychology \& Marketing, 10, 449465. https://doi.org/10.1002/mar.4220100507

[13] Hejmadi, M.V., Bullock, K., Gould, V. and Lock, G.D. (2011) Is Choosing to Go on Placement a Gamble? Perspectives from Bioscience Undergraduates. Assessment \& Evaluation in Higher Education, 37, 605-618. https://doi.org/10.1080/02602938.2011.557714

[14] Knemeyer, A.M. and Murphy, P.R. (2002) Logistics Internships: Employer and Student Perspectives. International Journal of Physical Distribution \& Logistics Management, 32, 135-152. https://doi.org/10.1108/09600030210421732

[15] Dickerson, J.P. (2009) The Realistic Preview May Not Yield Career Satisfaction. International Journal of Hospitality Management, 28, 297-299.

https://doi.org/10.1016/j.ijhm.2008.06.015

[16] Lee, S.A. (2008) Increasing student learning: A Comparison of Students' Perceptions of Learning in the Classroom Environment and Their Industry-Based Experiential Learning Assignments. Journal of Teaching in Travel \& Tourism, 7, 37-54. https://doi.org/10.1080/15313220802033310

[17] Garavan, T.N. and Murphy, C. (2001) The Co-Operative Education Process and Organisational Socialisation: A Qualitative Study of Student Perceptions of Its Effectiveness. Education+Training, 43, 281-302. https://doi.org/10.1108/EUM0000000005750

[18] Spowart, J. (2006) Hotel School Students' Views of Their Preparation for Work-Integrated Learning: An Exploratory Study. Asia-Pacific Journal of Cooperative Edu- 
cation, 7, 10-15.

[19] Lin, Y.H. (2006) The Incidence of Sexual Harassment of Students While Undergoing Practicum Training Experience in the Taiwanese Hospitality Industry-Individuals Reactions and Relationships to Perpetrators. Tourism Management, 27, 5168. https://doi.org/10.1016/j.tourman.2004.06.018

[20] Taylor, M.S. (1988) Effects of College Internships on Individual Participants. Journal of Applied Psychology, 73, 393-401. https://doi.org/10.1037/0021-9010.73.3.393

[21] Aggett, M. and Busby, G. (2011) Opting Out of Internship: Perceptions of Hospitality, Tourism and Events Management Undergraduates at a British University. Journal of Hospitality, Leisure, Sport \& Tourism Education, 10, 106-113.

https://doi.org/10.3794/johlste.101.310

[22] Fidgeon, P.R. (2010) Tourism Education and Curriculum Design: A Time for Consolidation and Review? Tourism Management, 31, 699-723.

https://doi.org/10.1016/j.tourman.2010.05.019

[23] Kwok, L., Adams, C.R. and Price, M.A. (2011) Factors Influencing Hospitality Recruiters' Hiring Decisions in College Recruiting. Journal of Human Resources in Hospitality \& Tourism, 10, 372-399. https://doi.org/10.1080/15332845.2011.588571

[24] Hiltebeitel, K.M., Leauby, B.A., Larkin, J.M. and Morris, T.W. (2000) Job Satisfaction among Entry-Level Accountants. CPA Journal, 70, 76-78.

[25] Cook, S.J., Parker, R.S. and Pettijohn, C.E. (2004) The Perceptions of Interns: A Longitudinal Case Study. Journal of Education for Business, 79, 179-185.

[26] Chen, F.C., Ku, E.C.S, Shyr, Y.H., Chen, F.H. and Chou, S.S. (2009) Job Demand, Emotional Awareness, and Job Satisfaction in Internships: The Moderating Effect of Social Support. Social Behavior and Personality: An International Journal, 37, 14291440. https://doi.org/10.2224/sbp.2009.37.10.1429

[27] Oliver, R.L. (1980) A Cognitive Model of the Antecedents and Consequences of Satisfaction Decisions. Journal of Marketing Research, 17, 460-469. https://doi.org/10.1177/002224378001700405

[28] Kim, H.B. and Park, E.J. (2013) The Role of Social Experience in Undergraduates' Career Perceptions through Internships. Journal of Hospitality, Leisure, Sport \& Tourism Education, 12, 70-78. https://doi.org/10.1016/j.jhlste.2012.11.003

[29] Ruhanen, L., Robinson, R. and Breakey, N. (2013) A Tourism Immersion Internship: Student Expectations, Experiences and Satisfaction. Journal of Hospitality, Leisure, Sport \& Tourism Education, 13, 60-69.

https://doi.org/10.1016/j.jhlste.2013.02.001

[30] Waryszak, R.Z. (1999) Students' Expectations from Their Cooperative Education Placements in the Hospitality Industry: An International Perspective. Education + Training, 41, 33-40. https://doi.org/10.1108/00400919910255924

[31] Barron, P. (2008) Education and talent management: Implications for the hospitality industry. International Journal of Contemporary Hospitality Management, 20, 730-742. https://doi.org/10.1108/09596110810897583

[32] Chen, T.L. and Shen, C.C. (2012) Today's Intern, Tomorrow's Practitioner?-The Influence of Internship Programmes on Students' Career Development in the Hospitality Industry. Journal of Hospitality, Leisure, Sport \& Tourism Education, 11, 29-40. https://doi.org/10.1016/j.jhlste.2012.02.008

[33] Krosnick, J.A. (1988) The Role of Attitude Importance in Social Evaluation: A Study of Policy Preferences, Presidential Candidate Evaluations, and Voting Behavior. Journal of Personality and Social Psychology, 55, 196-210.

https://doi.org/10.1037/0022-3514.55.2.196 
[34] Richardson, S. (2009) Undergraduates' Perceptions of Tourism and Hospitality as a Career Choice. International Journal of Hospitality Management, 28, 382-388. https://doi.org/10.1016/j.ijhm.2008.10.006

[35] Pounder, D.G. and Merrill, R.J. (2001) Job Desirability of the High School Principalship: A Job Choice Theory Perspective. Educational Administration Quarterly, 37, 27-57. https://doi.org/10.1177/0013161X01371003

[36] Lawler III, E.E., Kuleck, W.J., Rhode, J.G. and Sorensen, J.E. (1975) Job Choice and Post Decision Dissonance. Organizational Behavior and Human Performance, 13, 133-145. https://doi.org/10.1016/0030-5073(75)90009-4

[37] Van Eerde, W. and Thierry, H. (1996) Vroom's Expectancy Models and Work-Related Criteria: A Meta-Analysis. Journal of Applied Psychology, 81, 575-586. https://doi.org/10.1037/0021-9010.81.5.575

[38] Wanous, J.P., Keon, T.L. and Latack, J.C. (1983) Expectancy Theory and Occupational/Organizational Choices: A Review and Test. Organizational Behavior and $\mathrm{Hu}$ man Performance, 32, 66-86. https://doi.org/10.1016/0030-5073(83)90140-X

[39] Behling, O., Labovitz, G and Gainer, M. (1968) College Recruiting: A Theoretic Base. Personnel Journal, 47, 13-19.

[40] Chapman, D. and Webster, J. (2006) Toward an Integrated Model of Applicant Reactions and Job Choice. International Journal of Human Resource Management, 17, 1032-1057. https://doi.org/10.1080/09585190600696572

[41] Mahony, D.F., Mondello, M., Hums, M.A. and Judd, M. (2006) Recruiting and Retaining Sport Management Faculty: Factors Affecting Job Choice. Journal of Sport Management, 20, 414-430. https://doi.org/10.1123/jsm.20.3.414

[42] Boswell, W.R., Roehling, M.V., LePine, M.A. and Moynihan, L.M. (2003) Individual Job-Choice Decisions and the Impact of Job Attributes and Recruitment Practices: A Longitudinal Field Study. Human Resource Management, 42, 23-37. https://doi.org/10.1002/hrm.10062

[43] Bundy, P. and Norris, D. (1992) What Accounting Students Consider Important in the Job Selection Process. Journal of Applied Business Research, 8, 1-6.

[44] Cable, D.M. and Turban, D.B. (2003) The Value of Organizational Reputation in the Recruitment Context: A Brand-Equity Perspective. Journal of Applied Social Psychology, 33, 2244-2266. https://doi.org/10.1111/j.1559-1816.2003.tb01883.x

[45] Cable, D.M. and Judge, T.A. (1996) Person-Organization Fit, Job Choice Decisions, and Organizational Entry. Organizational Behavior and Human Decision Processes, 67, 294-311. https://doi.org/10.1006/obhd.1996.0081

[46] Aycan, Z. and Fikret-Pasa., S. (2003) Career Choices, Job Selection Criteria, and Leadership Preferences in a Transitional Nation: The Case of Turkey. Journal of Career Development, 30, 129-144. https://doi.org/10.1177/089484530303000203

[47] Busby, G. (2003) Tourism Degree Internships: A Longitudinal Study. Journal of Vocational Education \& Training, 55, 319-334. https://doi.org/10.1080/13636820300200232

[48] Tse, T.S.M. (2010) What Do Hospitality Students Find Important about Internships? Journal of Teaching in Travel \& Tourism, 10, 251-264.

https://doi.org/10.1080/15313221003792027 